\title{
PERAN ORANG TUA DALAM MEWARISKAN IMAN BAGI PEMBINAAN ROHANI ANAK REMAJA MENURUT 2 TIMOTIUS 1:5 DALAM ERA REVOLUSI INDUSTRI 4.0
}

\author{
Oleh: \\ Yosua Sibarani \\ Dosen Tetap Sekolah Tinggi Teologi Happy Family \\ Email: yosuasibarani@stthf.ac.id
}

\begin{abstract}
ABSTRAK - Kemajuan ilmu pengetahuan dan teknologi dalam era revolusi industri 4.0 turut menyeret kehidupan anak remaja ke dalam berbagai penyalahgunaan dan penyimpangan. Ada banyak kenakalan remaja yang terjadi di dalam masyarakat seperti pergaulan bebas, merokok, tawuran, minuman keras dan obat-obat terlarang, bahkan seks di luar nikah. Hal tersebut dapat disebabkan kurangnya peran orang tua dalam mewariskan nilai-nilai kerohanian kepada anak remaja. Dengan demikian, tujuan penelitian ini adalah untuk menjelaskan peran orang tua dalam mewariskan iman kepada anak remaja berdasarkan 2 Timotius 1:5. Penulis membatasi penelitian ini pada pembinaan rohani anak remaja. Untuk mencapai tujuan tersebut, maka penulis menerapkan metode penelitian kualitatif deskriptif dengan pendekatan studi literatur. Dalam hal ini, penulis juga menganalisis teks 2 Timotius 1:5 melalui prinsip hermeneutik Perjanjian Baru untuk mendapatkan peran orang tua dalam mewariskan iman bagi pembinaan rohani anak remaja. Sebagai hasil dari penelitian ini, peran orang tua dalam mewariskan iman kepada anak remaja adalah sebagai pendidik (edukator), sebagai pembimbing (mentor), dan sebagai pendorong (motivator).
\end{abstract}

Kata Kunci: Warisan Iman; Anak Remaja; Pembinaan Rohani; 2 Timotius 1:5

ABSTRACT - The advancement of science and technology in the industrial revolution era 4.0 also dragged the lives of teenagers into various abuses and deviations. There are many juvenile delinquencies that occur in society such as promiscuity, smoking, brawl, alcohol and drugs, and even sex outside of marriage. This can be due to the lack of the role of parents in passing on spiritual values to adolescents. Thus, the purpose of this study is to explain the role of parents in passing on faith to adolescents based on 2 Timothy 1: 5. The author limits this research to the spiritual formation of adolescents. To achieve these objectives, the authors apply descriptive qualitative research methods with a literature study approach. In this case, the author also analyzes the text of 2 Timothy 1:5 through the New Testament hermeneutic principles to get the role of parents in passing on faith for the spiritual formation of adolescents. As a result of this study, the role of parents in passing on faith to adolescents is as educators, as mentors, and as motivators.

Keywords: Faith Heritage; Teenager; Spiritual Formation; 2 Timothy 1: 5 


\section{PENDAHULUAN}

Perkembangan kepribadian seorang anak pada hakekatnya ikut dibentuk oleh masyarakat di mana ia dibesarkan. ${ }^{1}$ Demikian halnya pada masa remaja, pengalaman dan lingkungan masyarakat berpengaruh besar dalam pertumbuhan kepribadian anak remaja. Usia remaja adalah suatu masa dari tahap kehidupan yang dilalui oleh manusia. Menurut Hurlock, usia remaja berlangsung pada rentang 13-18 tahun. ${ }^{2}$ Pada masa ini, seorang anak akan mengalami perubahan fisik dan psikis. Mereka sedang berada pada wilayah pencarian jati diri, ke mana mereka akan melangkah di masa depan. Dalam usaha pencarian jati diri tersebut, mereka akan berupaya melakukan hal-hal yang menurut mereka baru, termasuk hal-hal buruk. Remaja pada saat ini lebih dikenal dengan iGeneration yang lahir pada tahun 1995-2002 yang tumbuh dalam ketergantungan pada teknologi digital dan internet. ${ }^{3}$ Dorongan dari dalam diri remaja untuk mencari jati diri dapat menjerumuskan

\footnotetext{
${ }^{1}$ N. K. A. Hadinoto, Dialog Dan Edukasi (Jakarta: BPK Gunung Mulia, 1999), 233.

2 Elizabeth B. Hurlock, Psikologi Perkembangan: Suatu Pendekatan Sepanjang Rentang Kehidupan (Jakarta: Erlangga, 2002).

3 Wandi Adiansah et al., "Person in Environment Remaja Pada Era Revolusi Industri 4.0," Focus : Jurnal Pekerjaan Sosial 2, no. 1 (2019): 47.
}

mereka ke dalam berbagai penyalahgunaan dan penyimpangan. Oleh sebab itu pembentukan spiritual bagi anak remaja merupakan sesuatu yang sangat penting.

Pembinaan rohani sejak usia dini hingga remaja merupakan tugas penting orang tua. Orang tua adalah pihak yang pertama dan utama dalam melakukan pembinaan rohani remaja. ${ }^{4}$ Yakub Susabda berpendapat bahwa pembinaan rohani anak adalah tanggung jawab orang tua yang sangat besar. ${ }^{5}$ Peran orang tua sangat diperlukan dalam pembentukan kehidupan rohani anak dan peran ini dimulai dari keluarga. Hal ini bermanfaat bagi persiapan anak remaja untuk memasuki masa dewasa hingga tuanya. Orang tua sangat berperan penting bagi pembentukan iman anak di samping gereja yang mendampingi keluarga. Namun, banyak orang tua tidak menyadari hal tersebut. ${ }^{6}$ Orang tua merasa bahwa pembinaan rohani anak remaja adalah tugas dan tanggung jawab gereja semata. Pemikiran seperti itulah yang mengakibatkan banyak orang tua

4 Roswitha Ndraha and Julianto Simanjuntak, Sembilan Masalah Utama Remaja (Jakarta: Yayasan Peduli Konseling Indonesia, 2009), viii.

${ }^{5}$ Yakub Susabda, Marriage Enrichment: Pembinaan Keluarga Kristen (Jakarta: Mitra Pustaka dan Pionir Jaya, 2011), 139.

6 Lawrence O. Richards, Pelayanan Kepada Anak-Anak (Bandung: Kalam Hidup, 2007), 262. 
Kristen yang tidak mempedulikan perannya dalam pertumbuhan rohani anak-anaknya, khususnya remaja. Sikap ini adalah sikap yang keliru. Tuhan menciptakan keluarga sebagai salah satu wadah penting bagi pembentukan kerohanian seluruh anggota keluarga, baik orang tua dan anak-anak.

Mario Fantini dan Rene Cardenas melakukan peninjauan terhadap sejumlah perubahan yang signifikan dalam kehidupan keluarga. Berdasarkan hasil penelitian mereka, peran orang tua sedang berubah. Antara tahun 1970 dan 1973 terjadi peningkatan sebesar $18 \%$ di mana perempuan berfungsi sebagai kepala keluarga, dibanding dengan $24 \%$ kenaikan dalam dekade sebelumnya. Adapaun pada akhir tahun 1970-an kira-kira 12,4\% dari keluarga Amerika dikepalai oleh perempuan, dan $60 \%$ dari keluarga ini memiliki anak-anak di bawah usia 6 tahun. Memasuki tahun 1980an setengah dari keluarga yang sedang membesarkan anak di bawah enam tahun adalah keluarga dengan orang tua tunggal, karena peningkatan perceraian yang terus meningkat dalam keluarga yang mempunyai anak. $^{7}$

7 Mario Fantini and Rene Cardenas, Parenting in a Multiculture Society (New York: Longman, 1980), 262.
Anak remaja yang tidak mendapatkan pembinaan rohani dari orang tua akan mudah terpengaruh oleh lingkungan yang buruk. Adapun pengaruh negatif yang muncul dalam diri anak adalah kehidupan yang tidak terkontrol. Salah satu hal yang dapat memberikan pengaruh buruk bagi anak remaja adalah media dan teknologi yang berkembang dengan pesat saat ini. Roswitha Ndraha dan Julianto Simanjuntak berpendapat bahwa orang tua harus memberikan filter kepada anak berkaitan dengan penggunaan media dan teknologi supaya anak dapat memahami hal yang berkenan kepada Tuhan. ${ }^{8}$ Jika tidak, maka teknologi yang berperan sebagai mediator antara anak dan dunia. Dengan cara itu, dunia akan "menggendong" dan "membelai" kehidupan remaja.

Era revolusi industri 4.0 memberikan tantangan serius bagi orang tua untuk membina anak remaja supaya mereka tidak menjadi korban kemajuan dan perkembangan teknologi pada era ini. Era revolusi industri 4.0 yang ditandai dengan penemuan kecerdasan buatan dalam mesin menyebabkan perkembangan anak pada era ini berbeda dengan era sebelumnya. Salah

8 Ndraha and Simanjuntak, Sembilan Masalah Utama Remaja, $x$. 
satunya adalah masalah interaksi sosial yang dulu dilakukan secara langsung dengan tatap muka, sekarang kerap kali dilakukan secara daring di dunia maya. ${ }^{9}$ Fenomena tersebut dapat mempengaruhi karakter anak menjadi orang yang tidak peduli orang lain dan tidak menutup kemungkinan menghadirkan karakter-karakter buruk lainnya dalam diri remaja Kristen.

Kemajuan ini pun berdampak pada terjadinya perubahan pada bidang lainnya, seperti bidang sosial, ekonomi, dan budaya. Meskipun ada dampak positif yang ditimbulkan, namun pada akhirnya, dampak yang ditimbulkan itu cenderung lebih ke arah negatif. Peran orang tua sangat diperlukan untuk membimbing dan mengarahkan remaja dalam menghadapi perkembangan IPTEK dewasa ini. ${ }^{10}$ Elizabeth B. Hurlock juga pernah menuliskan bahwa masa remaja adalah satu masa kehidupan manusia yang

${ }^{9}$ Ruat Diana, "Prinsip Teologi Kristen Pendidikan Orang Tua Terhadap Anak Di Era Revolusi Industri 4.0," BIA': Jurnal Teologi dan Pendidikan Kristen Kontekstual 2, no. 1 (2019): 27-39.

${ }^{10}$ Santy Sahartian, "Pengaruh Pembinaan Rohani Keluarga Terhadap Karakter Pemuda Berdasarkan Kolose 2: 6-10 Di GBAP Surakarta," FIDEI: Jurnal Teologi Sistematika dan Praktika 2, no. 1 (2019): 20-39.

11 Elizabeth B. Hurlock, Psikologi Perkembangan: Suatu Pendekatan Sepanjang Rentang Kehidupan (Jakarta: Erlangga, 1994), 208. penuh tantangan dan perubahan. Meskipun tiap periode memiliki tantangannya masingmasing, namun remaja sering kali kurang mampu menangani masalah itu sesuai yang diharapkan. ${ }^{11}$ Tentunya perubahan masa itu lebih mudah dipengaruhi oleh siklus sosial dan berakibat pada perilaku spiritual remaja masa kini.

Hal di atas dapat tercermin dalam berbagai fenomena remaja di Indonesia mulai dari tawuran, perilaku seks bebas, keterlibatan dalam narkoba, alkohol, dan kriminalitas. ${ }^{12}$ Ada beberapa berita tentang kenakalan remaja yang tersebar di media massa. Salah satunya adalah seorang siswa meminum minuman keras berupa anggur merah viral di media sosial. Dalam berbagai akun yang menggunggah video tersebut disebutkan bahwa lokasinya berada di Jakarta Utara. $^{13}$ Tidak hanya itu, di Bantul pernah terjadi peristiwa kekerasan yang dilakukan

12 Kusmiyati, "Berbagai Perilaku Kenakalan Remaja Yang Mengkhawatirkan Health Liputan6.Com," last modified September 10, 2013, accessed January 24, 2021, https://www.liputan6.com/health/read/688614/b erbagai-perilaku-kenakalan-remaja-yangmengkhawatirkan.

13 "Viral Video Siswa Minum Anggur Merah Di Kelas, Lokasi Diduga Bukan Daerah Jakarta Utara," accessed January 24, 2021, https://megapolitan.kompas.com/read/2019/09/0 2/22383871/viral-video-siswa-minum-anggurmerah-di-kelas-lokasi-diduga-bukan-daerah. 
oleh rombongan pelajar kepada pelajar lain. Awi Setiyono selaku Kepala Bagian Mitra Divisi Humas mengatakan bahwa hal tersebut adalah bentuk kenakalan remaja yang terjadi. ${ }^{14}$

Berdasarkan kasus di atas, orang tua adalah pemeran utama dalam pertumbuhan dan perkembangan rohani remaja. Keluarga adalah hal yang paling berpengaruh dalam pembentukan kerohanian remaja Kristen. Sebuah data penelitian menuliskan bahwa $29,4 \%$ perkembangan remaja adalah orang tua atau keluarga. 26,87\% faktor pergaulan atau teman, $20 \%$ faktor sekolah, $15 \%$ faktor gereja, $4 \%$ faktor media. ${ }^{15}$ Kemudian diikuti faktor perlakuan buruk orang tua terhadap anak, perselisihan atau konflik, dan perceraian orang tua. Hal inilah yang menjadi faktor yang mempengaruhi perilaku menyimpang remaja. Survey lain menuliskan bahwa 46,25 \% responden menyatakan bahwa kegagalan perkembangan rohani anak adalah karena kurangnya bimbingan. Hal tersebut disebabkan karena orang tua dalam

\footnotetext{
14 "Polisi Anggap Penganiayaan Rombongan Pelajar Di Bantul Sebagai Kenakalan Remaja," accessed January 24, 2021, https://nasional.kompas.com/read/2016/12/14/18 072041/polisi.anggap.penganiayaan.rombongan. pelajar.di.bantul.sebagai.kenakalan.remaja.

15 Livia Yuliawati and Bhaktiar
} Sihombing, "Membangun Karakter: Sekilas keluarga terlalu sibuk dengan kegiatankegiatan masing-masing. ${ }^{16}$

Orang tua Kristen harus melakukan pembinaan rohani terhadap anak remajanya supaya menjadi anak remaja yang mempermuliakan Tuhan melalui iman dan karakternya. Pembinaan rohani tersebut merupakan sebuah upaya yang dilakukan secara sadar sebagai mandat dari Allah bagi orang tua untuk membimbing dan membentuk remaja Kristen keluar dari gaya hidup ciptaan yang lama kepada gaya hidup anak-anak terang di dalam Kristus (2 Kor. 5:17). Perubahan tersebut mencakup pada spiritual, pikiran, perilaku, dan pengetahuan. Karakter merupakan ciri unik pribadi yang dimiliki manusia yang terkait dengan prinsip dan nilai hidup yang mempengaruhi pikiran, sikap, serta perilaku. ${ }^{17}$ Yesus adalah gambar Allah yang memiliki segala sifat, karakteristik, dan kulitas yang terdapat dalam diri Allah Bapa. ${ }^{18}$ Karakter Kristus itu yang harus ditanamkan dalam diri remaja Kristen saat ini. Hal itu bertujuan supaya remaja

Potret Kebutuhan Remaja Di Sekolah Kristen," Jurnal Teologi Reformed Indonesia 4, no. 1 (2014): 19-28.

${ }^{16}$ Ibid.

${ }^{17}$ Ibid.

18 Anthony A. Hoekema, Manusia: Ciptaan Menurut Gambar Allah (Surabaya: Momentum, 2003), 28. 
Kristen dapat mempertahankan karakter Kristus di tengah-tengah tantangan dunia ini.

Secara singkat, masalah yang melatarbalakangi penulisan ini adalah kurangnya pembinaan rohani orang tua kepada anak-anak remaja. Orang tua belum memahami secara tepat peran mereka dalam melakukan pembinaan kepada anak remaja. Oleh karena itu, orang tua Kristen memerlukan suatu petunjuk pembinaan rohani berdasarkan Alkitab untuk mengembangkan rohani anak remaja. Dengan demikian, setiap orang tua Kristen mampu berperan serta dalam pembinaan rohani anak remaja sehingga anak remaja tumbuh menjadi saksi Kristus di manapun mereka berada.

\section{RUMUSAN MASALAH}

Adapun rumusan masalah penelitian ini adalah apa peran yang dimiliki dan harus dilakukan oleh orang tua dalam mewariskan iman bagi pembinaan rohani remaja menurut 2 Timotius $1: 5$ ?

Artikel ini bertujuan menjelaskan peran orang tua dalam mewariskan iman bagi pembinaan rohani remaja menurut 2 Timotius 1:5.

${ }^{19}$ Andreas B. Subagyo, Pengantar Riset Kuantitatif Dan Kualitatif (Bandung: Kalam Hidup, 2004), 62.
Artikel ini memberikan dua manfaat, yaitu: Pertama, secara teoritis menambah wawasan teologi praktika bagi mahasiswamahasiswa Sekolah Tinggi Teologi. Kedua, secara praktis orang tua Kristen memiliki kemampuan dalam menjalankan perannya untuk mewariskan iman bagi pembinaan rohani anak remaja.

\section{METODE PENELITIAN}

Berdasarkan permasalahan dan tujuan penelitian ini, maka penulis menggunakan metode penelitian kualitatif dengan pendekatan deskriptif analisis. Metode kualitatif ini lebih menekankan proses penemuan dan lebih menekankan penjelasan. ${ }^{19}$ Pendekatan deskriptif analisis merupakan suatu metode yang meneliti keadaan sebuah komunitas, suatu objek, set kondisi, paradigma maupun fenomena yang sedang terjadi. ${ }^{20}$ Oleh sebab itu, penelitian ini menjelaskan peran orang tua bagi pembinaan rohani remaja berdasarkan 2 Timotius 1:5. Dengan metode kualitatif dan pendekatan deskriptif analisis, penulis melakukan analisis 2 Timotius 1:5 berdasarkan prinsip hermeneutika Perjanjian Baru khususnya teks yang bergenre surat. Selanjutnya,

20 Moh. Nazir, Metode Penelitian (Jakarta: Ghalia Indonesia, 1988), 63. 
penulis mengumpulkan dan mengklasifikasikan data-data yang berkaitan dengan fokus penelitian ini dari beberapa kepustakaan yang tersedia dan relevan. Kemudian data-data dari hasil studi eksposisi dan literatur tersebut penulis sajikan (display) dalam pembahasan. Pada bagian akhir, penulis memberikan jawaban atas rumusan masalah penelitian yang menjadi kesimpulan penelitian.

\section{HASIL DAN PEMBAHASAN}

\section{Latar Belakang Historis Surat 2 Timotius}

Surat 2 Timotius dikenal sebagai surat penggembalaan bersamaan dengan surat 1 Timotius dan Titus. Sebutan surat penggembalaan pertama kali diberikan oleh seorang ahli berkebangsaan Jerman, Paul Anton pada tahun $1726 .{ }^{21}$ Surat 2 Timotius membicarakan masalah-masalah utama yang dihadapi oleh Timotius dalam menjalani panggilan mereka sebagai pemimpin dalam gereja. ${ }^{22}$ Surat 2 Timotius ditulis oleh Paulus kepada Timotius. Meskipun banyak ahli menyangkali kepenulisan Paulus atas surat-

${ }^{21}$ Donald Guthrie, The Pastoral Epistles: Tyndale New Testament Commentaries (Grand Rapids: Eerdmans Publishing Company, 1957), 11.

${ }^{22}$ Mark L. Bailey, "Teologi Dari SuratSurat Penggembalaan Paulus," in A Biblical Theology of New Testament, ed. Roy B. Zuck (Malang: Gandum Mas, 2011), 381. surat penggembalaan (termasuk 2 Timotius), namun karya-karya eksegesis dan eksposisi akhir-akhir ini memberikan pembelaan yang cukup untuk kepenulisan Paulus terhadap surat-surat penggembalaan. $^{23}$

Surat ini bersifat pribadi. Paulus menulis surat ini kepada Timotius yang sedang menghadapi berbagai masalah dalam pelayanan penggembalaannya di Efesus. Timotius juga harus melakukan antisipasi terhadap guru-guru palsu yang merusak iman jemaat yang dilayaninya. Oleh sebab itu, Paulus memberi nasihat dan pengajaran kepada Timotius untuk tetap memelihara Injil yang murni, memberitakan Firman Allah tanpa kenal lelah, bertahan menghadapi berbagai kesulitan, dan melaksanakan tugas pelayanan yang dipercayakan kepadanya. ${ }^{24}$ Surat ini merupakan surat yang ditulis oleh Paulus menjelang kematiannya di Roma. Paulus menggunakan waktu yang ada untuk menulis surat ini oleh dorongan dan inspirasi Roh Kudus. Beberapa orang berpendapat bahwa surat ini adalah amanat terakhir Paulus kepada Timotius. ${ }^{25}$ Oleh sebab itu,

$$
{ }^{23} \text { Ibid. }
$$

24 Alkitab Penuntun Hidup Berkelimpahan (Malang: Gandum Mas, 1994), 2032.

${ }^{25}$ M. E. Duyverman, Pembimbing Ke Dalam Perjanjian Baru (Jakarta: BPK Gunung Mulia, 2012), 164. 
surat ini merupakan surat terakhir Paulus yang ditulis menjelang kematiannya. ${ }^{26}$ Pada saat menulis surat ini, kekristenan di Romah sedang dihambat oleh kaisar Nero dengan melakukan penganiayaan yang sangat kejam. Paulus pun dipenjarakan di Roma untuk kedua kalinya sebagai tahanan negara karena Injil Yesus Kristus (2 Tim. 1:16). Banyak dari rekannya yang telah berpaling darinya ( 2 Tim. 1:15) dan dia dibelenggu seperti seorang penjahat (2 Tim. 2:9). Pada saat genting seperti itulah dia menyadari bahwa tugas pelayanannya akan berakhir dan kematiannya pun sudah dekat (2 Tim. 4:6-8, 18). Oleh sebab itu Paulus perlu memberikan beberapa nasihat kepada Timotius terkait masalah pelayanan Timotius di kota Efesus sebelum masa hidupnya habis.

\section{Analisis Konteks}

Secara spesifik, perikop dalam 2 Timotius 1:3-18 merupakan ucapan syukur rasul Paulus kepada Allah dan permohonan doanya kepada Allah tentang Timotius (2 Tim. 1:3). Sebuah surat dibuka dengan doa bagi kesejahteraan umum (general welfare) dan kesehatan (good health) bagi

26 Ola Tulluan, Introduksi Perjanjian Baru (Batu: Departemen Literatur YPPII, 1999), 230. pembacanya dalam kebudayaan Yunani,. ${ }^{27}$ Paulus memberikan nasihat kepada Timotius untuk bertekun dalam iman dan panggilan pelayanannya (2 Tim. 1:5-6). Dia juga mendorong Timotius untuk tidak malu bersaksi tentang Tuhan dan memegang segala ajaran yang diberikan kepadanya (2 Tim. 8-14). Jadi, dalam pasal 1 ini, Paulus memberikan pujian dan pengakuan kepada Timotius tentang iman Timotius dengan sebutan "iman yang tulus ikhlas" yang “diwariskan” oleh nenek dan ibunya. Paulus menyebutkan Timotius sebagai "anakku yang kekasih" (2 Tim. 1:2) dan teman sekerja yang setia (bdk. Rm. 16:21). Hal itu mendeskripsikan betapa dekatnya relasi di antara mereka.

Paulus melihat, bahwa penghayatan iman yang tulus juga ada pada diri Timotius. Hal ini dibuktikan dalam ayat 5 yang mengandung frase "imanmu yang tulus ikhlas". Timotius telah mewarisi iman dari ibu dan neneknya. Paulus mengenal iman yang dimiliki oleh Timotius yang tidak lepas dari peran ibu dan neneknya. Mereka berdua telah memberikan pengajaran, teladan, dan dorongan kepada Timotius sejak masa

\footnotetext{
${ }^{27}$ Gordon D. Fee, 1 and 2 Timothy, Titus: New International Biblical Commentary (Massachusetts: Hendrickson Publishers, 1988), 220.
} 
kecilnya tentang Perjanjian Lama (2 Tim. 3:14-15). Setelah mereka menjadi pengikut Kristus, mereka tetap mendampingi Timotius untuk tetap hidup di dalam iman kepada Yesus (Bdk. Kis. 16:1-2). ${ }^{28}$

\section{Temuan Teologis}

Surat 2 Timotius 1:5 memberikan sebuah contoh pentingnya peran orang tua dalam pembinaan rohani (karakter Kristiani) anak sejak remaja. Pengaruh yang paling dominan dalam pembentukan karakter seseorang adalah genetika dan keluarga asalnya. ${ }^{29}$ Tidak dapat dipungkiri bahwa iman bukan aspek yang diwarisi secara langsung dari orang tua, tetapi iman anak dapat terbentuk dan bertumbuh melalui pembinaan, pemberian teladan orang tua anak tersebut. Alasan penulis melandasi peran orang tua dalam pembinaan remaja Kristen berdasarkan surat 2 Timotius 1:5 adalah karena perintah hidup dalam kebenaran adalah mutlak dalam Firman Tuhan, dan masa depan perkembangan rohani remaja Kristen adalah tanggung jawab orang tua secara khusus. Dalam ayat 5 dituliskan adanya peran orang tua Timotius,

${ }^{28}$ Donald Guthrie et al., Tafsiran Alkitab Masa Kini 3: Matius-Wahyu (Jakarta: Yayasan Komunikasi Bina Kasih, 2006), 703.

${ }^{29}$ John R. W. Stott, Pemahaman Dan Penerapan Amanat 2 Timotius (Jakarta: Yayasan Komunikasi Bina Kasih, 1991), 27. yaitu Eunike dan neneknya Louis dalam pembinaan rohani Timotius. Berkaitan dengan hal itu, Paulus sebagai bapak rohani Timotius pun mengakui keberhasilan pembinaan rohani yang dialami oleh Timotius.

Berdasarkan analisis latar belakang historis, konteks, dan gramatikal di atas, maka penulis mendeskripsikan temuan teologis 2 Timotius 1:5 sebagai berikut:

\section{Iman yang Tulus Ikhlas}

Paulus menuliskan bahwa ia mengingat tentang iman Timotius yang tulus ikhlas di dalam Tuhan Yesus. Dalam terjemahan bahasa Inggris ditulis, "I have been reminded" yang berarti "having received a reminder" (Yunani: hypomenesin labon). Kata benda "hypomnesis" (hanya terdapat dalam ayat ini dan 2 Pet. $1: 13 ; 3: 1$ ), adalah sebuah kegiatan memori. ${ }^{30}$ J. A. Bengel menulis, "Some external occasion or a message from Timothy, had brought his faith to Paul's remembrance" (beberapa kesempatan eksternal atau sebuah pesan dari Timotius, telah membawa imannya kepada

${ }^{30}$ Frank E. Gaebelein, The Expositor's Bible Commentary Volume 11 (Grand Rapids: Zondervan Publishing House, n.d.), 394. 
ingatan Paulus). ${ }^{31}$ Paulus mengatakan bahwa iman Timotius adalah iman yang tulus ikhlas. Frase "tulus ikhlas" secara literal berarti unhypocritical (tidak munafik). Timotius memiliki iman yang benar-benar sejati dan tidak semu. Bahkan Paulus memberikan pujian kepada Timotius atas imannya tersebut.

Iman tidak dapat bertumbuh secara otomatis, tetapi juga melalui pengajaran. Firman Tuhan berkata bahwa iman timbul dari pendengaran oleh firman Kristus (Rm. 10:17). Hal inilah yang dilakukan oleh Lois dan Eunike kepada Timotius dengan terus memperdengarkan firman Tuhan. Paulus memiliki seorang ayah berkebangsaan Yunani, dan ibu seorang Yahudi (Kis. 16:1, 3). Meskipun demikian, nenek dan ibu Timotius telah berhasil membina rohaninya dengan baik. Kisah Para Rasul 16:2 mengatakan bahwa Timotius dikenal baik oleh orang-orang percaya di Listra dan Ikonium. Hal itu membuktikan bahwa Timotius benar-benar hidup mempraktekkan iman yang tulus ikhlas di hatinya lewat tindakan dan perbuatannya. Iman itulah yang mempengaruhi hidup Timotius.

${ }^{31}$ Ibid.

${ }^{32}$ Fee, 1 and 2 Timothy, Titus: New International Biblical Commentary, 223.
Iman yang tulus ikhlas berbicara tentang iman yang murni (genuine faith), tidak ada kepalsuan atau keraguan kepada Tuhan. ${ }^{32}$ Iman yang murni ini merupakan iman yang tidak mengandung unsur kemunafikan. Artinya iman tersebut lahir dari keintiman dan kasih kepada Allah, bukan sebuah kamuflase untuk mendapatkan pengakuan atau penghargaan dari orang lain. Kualitas iman seseorang dapat terlihat ketika ia mengalami tekanan atau persoalan dalam hidup. Respon Timotius dalam menghadapi berbagai masalah dan ancaman dalam pelayanannya telah membuktikan kualitas imannya. Dalam pelayanannya, Timotius harus menghadapi berbagai karakter orang yang kurang menghargai dia sebagai anak muda (1 Tim. 4:12). Ia tidak mudah tawar hati dan patah semangat menghadapi tantangan dalam hidup dan pelayanannya tersebut karena ia memiliki iman yang sejati. Bahkan ia mampu menghadapi penderitaan dan pengajaran sesat dari guru-guru palsu berkat iman yang tulus ikhlas tersebut. ${ }^{33}$ Iman memberikan dia kemampuan untuk bertahan menghadapi badai kehidupan di masa mudanya.

${ }^{33}$ Ibid. 
Iman yang Diwariskan

Timotius dilahirkan dalam keluarga yang saleh. Timotius memiliki nenek dan ibu yang rohani dan takut akan Tuhan. Paulus menuliskan bahwa iman tulus ikhlas yang dimiliki oleh Timotius itu berasal dari iman neneknya yang bernama Lois dan diteruskan kepada ibunya yang bernama Eunike. Lalu Eunike mewariskan iman tersebut kepada Timotius hingga Timotius dipercayakan oleh Tuhan untuk memimpin gereja yang ada di Efesus. Dalam ayat-ayat ini Paulus mengunjuk leluhurnya sendiri "nenek moyangku" (ayat 3) dan juga ibu Timotius dan neneknya (ayat 5). Hal ini wajar sebab setiap orang adalah sebagian besar produk dari apa yang diwarisinya dari nenek moyangnya. ${ }^{34}$ Nenek dan ibu Timotius telah mengajar Timotius tentang Perjanjian Lama, sehingga "sejak kecil" ia telah mengenal Kitab Suci (2 Tim. 3:15). Calvin berpendapat bahwa Timotius kecil telah dididik secara ketat sehingga kerohanian itu seakan-akan diterimanya bersamaan air susu Eunike, ibunya. ${ }^{35}$ Pembinaan rohani melalui pengajaran firman Tuhan yang diwariskan oleh Lois dan Eunike telah mengubah kehidupan Paulus menjadi seorang pelayan Kristus. Paulus berkata bahwa ia yakin iman

34 Stott, Pemahaman Dan Penerapan Amanat 2 Timotius, 30. yang tulus ikhlas nenek dan ibu Timotius juga tinggal diam di dalam diri Timotius. Timotius telah menjaga warisan iman yang berharga tersebut dalam segala perilaku hidupnya.

Lois dan Eunike memanfaatkan segala peluang untuk mendidik Timotius sejak kecil dalam pengenalan tentang Alkitab. Lebih dari itu, mereka juga memberikan teladan melalui hidup mereka. Hasil yang luar biasa dari warisan iman Lois dan Eunike adalah karya Tuhan yang nyata dalam pribadi Timotius sebagai seorang gembala di kota Efesus dalam usia yang tergolong muda. Firman Tuhan yang menjadi terang dan pelita bagi kaki telah dipegang teguh oleh Paulus dan mengimplikasikannya dalam seluruh aspek kehidupan, termasuk pelayanannya.

\section{Peran Orang Tua dalam Pembinaan}

\section{Rohani Remaja Menurut 2 Timotius 1:5}

Anak remaja pada umumnya memiliki hubungan sosial yang renggang dengan orang tuanya. Mereka mulai enggan untuk meminta pendapat orang tua dalam melakukan sesuatu karena menganggap dirinya sudah mampu

${ }^{35}$ Ibid. 
mandiri. ${ }^{36}$ Orang tua pun seringkali memberikan respon yang salah terhadap kecenderungan anak remaja tersebut dengan melakukan pembatasan yang berujung pada pengekangan, bukan pembinaan. Hal yang perlu diperhatikan oleh setiap orang tua yang ingin mendidik anak remajanya adalah kepribadian dan dunia remaja itu sendiri. Mereka harus memahaminya dengan benar sebagai sebuah keunikan ciptaan Tuhan.

Orang tua tidak dapat menghindari keterlibatannya dalam era globalisasi dewasa ini. Orang tua memiliki respon yang beragam bila berhadapan dengan era globalisasi. Ada yang menarik diri (bubble way) terhadap perubahan tersebut. Di sisi lain ada yang menyerahkan diri atau tidak mau tahu tentang perubahan yang terjadi. Di samping kedua respon tersebut, ada juga yang bersikap kritis terhadap perubahan yang terjadi. Mereka lebih bersikap bijaksana menghadapi perkembangan yang ada. Oleh sebab itu, respon ini disebut sebagai smart way. ${ }^{37}$ Dari ketiga kategori reaksi tersebut, seyogyanya setiap orang

${ }^{36}$ Ramot Peter, "Peran Orangtua Dalam Krisis Remaja," Humaniora 6, no. 4 (2015): 453.

${ }^{37}$ Hellen Chou Pratama, Cyber Smart Parenting (Bandung: Visi Anugerah Indah, 2012), 25.

38 Nandari Prastica Wagiu, "Implementasi Peran Orang Tua Menurut tua memiliki sikap yang bijaksana atau kritis. Istilah "menerima dengan kritis" memiliki pengertian bahwa orang tua tidak hanya terbuka terhadap perubahan yang ada, namun juga memberikan filter terhadap perubahan dengan berlandaskan Alkitab sebagai firman Tuhan.

\section{Orang Tua Sebagai Pendidik (Edukator)}

Sebagai pendidik, orang tua mendapatkannya sebagai mandat dari Allah (U1. 6:4-9). ${ }^{38}$ Orang tua harus mendidik anak remaja dengan benar berdasarkan dengan pengajaran firman Tuhan supaya di masa yang akan datang ia dapat mengenal jati dirinya dan Penciptanya. ${ }^{39}$ Selain itu, didikan orang tua yang benar akan menuntun remaja berada di jalan yang (Ams. 22:6). Sebaliknya, apabila orang tua mengabaikan peran sebagai pendidik, maka anak dapat bertumbuh menjadi seorang pembuat masalah (trouble maker) dalam keluarga, masyarakat, gereja, dan negara. Hal yang fundamental bagi orang tua Kristen dewasa ini adalah menanam nilainilai kebenaran firman Tuhan dalam hidup remaja. Setiap orang tua perlu mengajarkan

Ulangan 6:4-9 Dalam Pendidikan Agama Kristen Keluarga Di Gereja Masehi Injili Di Minahasa Jemaat Imanuel Aertembaga Bitung," Shanan 2, no. 2 (2020): 128-161.

39 Marjoric L. Thompson, Keluarga Sebagai Pusat Pembentukan (Jakarta: BPK Gunung Mulia, 2011), 21. 
nilai-nilai tersebut kepada anak-anaknya dengan memperhatikan proses internalisasinya, yaitu proses penerimaan hingga pertumbuhan nilai kebenaran tersebut dalam diri remaja. ${ }^{40}$ Artinya orang tua tidak hanya memberikan materi pengajaran kepada anak, tetapi memastikan bahwa anak menerimanya dengan baik. jadi, tujuan orang tua dalam mendidik anak bukanlah mendikte, tetapi mengarahkan anak untuk mencari jalan hidup. ${ }^{41}$

Sebagai pendidik, orang tua harus mengajarkan firman Tuhan kepada remaja. Orang tua menerima tanggung jawab untuk memimpin anak-anak mereka ke arah warisan iman. Dengan kata lain, orang tua harus menjadi pribadi yang berdiri di depan untuk mengajarkan anak-anak mereka supaya memiliki kesetiaan kepada Tuhan melalui pengajaran firman-Nya. Komunitas gereja memang memiliki peran, tetapi orang tua diberikan tanggung jawab yang besar dalam mentransmisi iman kepada keturunannya. Gereja ada untuk membantu para orang tua dalam melakukannya. Gereja tidak boleh merebut peran orang tua karena warisan hanya didapat dari orang tua, demikian juga dengan warisan iman. Gereja

${ }^{40}$ Ibid.

41 Ndraha and Simanjuntak, Sembilan Masalah Utama Remaja, $x$. tidak bisa menggantikan peran yang Tuhan berikan kepada orang tua karena masingmasing memiliki mandat Ilahi yang unik dan tidak dapat ditukar satu dengan yang lain.

Di dalam Alkitab, Allah memberikan janji yang indah kepada Yeremia yang tetap berlaku untuk masing-masing generasi: "Sebab Aku ini mengetahui rancanganrancangan apa yang ada pada-Ku mengenai kamu, demikianlah firman Tuhan, yaitu rancangan damai sejahtera dan bukan rancangan kecelakaan, untuk memberikan kepadamu hari depan yang penuh harapan" (Yer. 29:11). Berdasarkan firman Tuhan tersebut, orang tua seharusnya dengan penuh tekad membantu anak-anak mereka menemukan rencana yang telah Allah tanamkan di dalam diri mereka. Orang tua mengajarkannya secara berulang-ulang, ketika berada di rumah, ketika sedang dalam perjalanan, ketika berbaring, dan ketika bangun dari tidur (Ul. 6:7). Hal ini tentu merupakan tugas yang tidak mudah bagi setiap orang tua. Namun kesadaran akan tanggung jawab tersebut akan memampukan orang tua melakukannya dengan sukacita. ${ }^{42}$ Tuhan yang menjadi sumber kekuatan yang

${ }^{42}$ Susie Wiriadinata, Orang Tua Idaman (Bandung: Lembaga Literatur Baptis, 1999). 
memberdayakan orang tua untuk menunaikan amanat yang diberikan-Nya.

Upaya pengajaran firman Tuhan oleh orang tua harus disertai dengan teladan. Setiap orang tua Kristen terpanggil untuk mengajarkan firman Tuhan kepada anakanak mereka (Ul. 6; Ams. 22:6) sehingga mereka harus mengenal kebenaran firman dan terus menerus memperlengkapi diri dengan bacaan-bacaan rohani. Hal ini bukan berarti bahwa orang tua harus jadi pengkhotbah. ${ }^{43}$ Pengajaran yang terdapat dalam kitab Amsal bersifat verbal. Hal tersebut tercermin dalam kitab Amsal bahwa semua yang diajarkan itu merupakan suatu "teladan hidup" (Ams. 20:7; 23:26; 13:20) bukan sekedar pengajaran semata. Sikap untuk meniru atau meneladai bukanlah sesuatu yang diajarkan kepada anak, namun sikap itu sudah ada pada diri anak ketika dilahirkan. Orang tua yang menjadi teladan yang baik dalam sebuah keluarga merupakan suatu komitmen yang harus diterapkan. Howard Hendrik mengatakan:

"Bahwa Anda tidak dapat memberikan apa yang Anda tidak ketahui. Anda tidak mengajarkan

43 Susabda, Marriage Enrichment: Pembinaan Keluarga Kristen, 136.

44 Howard Hendriks, Membina Temperamen Anda (Bandung: Kalam Hidup, 1982), 178. kepada anak Anda apa yang belum Anda ketahui sebelum seorang ayah atau ibu dapat membina keinginan anaknya terhadap hal-hal rohani, terlebih dahulu ia sendiri harus mempunyai pengalaman rohani dengan Kristus."44

Sebagaimana sebuah pernyataan mengatakan, "strong parents, strong children" memberikan kesadaran kepada orang tua bahwa sadar atau tidak sadar segala tindakan positif yang ditunjukkan oleh orang tua berdampak positif juta bagi keturunannya. ${ }^{45}$ Sebagaimana pendapat lain mengatakan bahwa pengajaran iman yang efektif harus dinyatakan melalui tindakan dan keteladanan sebagai tahap awal lalu kemudian dengan kata-kata. ${ }^{46}$ Teladan yang diberikan oleh orang tua dalam bersikap, keikutsertaan orang tua dalam kegiatan ibadah, kasih orang tua kepada Tuhan, kerinduan orang tua untuk membaca dan merenungkan firman Tuhan merupakan bahan dasar untuk memperkenalkan anak tentang Tuhan.

Orang Tua Sebagai Pembimbing (Mentor)

${ }^{45}$ Ann Grinnell, Pembacaan Wajib PAK Remaja-Pemuda (Makassar: STT Jaffray, 2012), 130.

46 Wes Haystead, Mengenalkan Allah Kepada Anak (Yogyakarta: Yayasan Gloria, 2000), 25. 
Sebagaimana penulis jelaskan di atas, sebagai pembimbing, orang tua berperan memberikan pembimbingan terhadap pertumbuhan rohani anak remaja. Orang tua seharusnya selalu mengawai dan mengontrol kehidupan rohani anak remaja mereka. Tentu hal ini membutuhkan energi dan waktu yang cukup banyak. Oleh sebab itu, orang tua harus benar-benar menyediakan energi dan waktu yang baik dan cukup untuk mengawasi pertumbuhan rohani anak-anak mereka. Sebagai contoh, orang tua sebaiknya selalu mengingatkan akan untuk selalu berdoa ketika ingin melakukan segala aktivitas setiap hari, seperti makan, belajar, mengikuti ujian, bepergian, dan lain-lain. Anak remaja harus disadarkan bahwa mereka harus bergantung kepada Tuhan yang berdaulat atas hidup mereka.

Orang tua yang bijak di hadapan Tuhan dan bagi anak-anaknya adalah mereka yang memenuhi kebutuhan rohani dan jasmani anak-anaknya. Dia tidak akan membiarkan dunia mengambil hal tersebut. Hal lain yang sangat penting untuk dilakukan oleh orang tua adalah mendoakan anakanaknya. Hal ini harus disadari oleh semua orang tua Kristen betapa pentingnya berdoa bagi anak-anak remaja mereka. Firman Tuhan berkata: "Doa orang yang benar, bila dengan yakin didoakan, sangat besar kuasanya (Yak. 5:16b)." Doa orang tua akan selalu melindungi anak remaja dari pengaruh-pengaruh buruk dan jahat di dalam pergaulan mereka.

Orang tua adalah wakil Allah di dunia bagi anak-anaknya. Sebagai wakil Allah, orang tua harus merepresentasikan Allah sebagai Bapa yang baik bagi anak-anak-Nya. Paulus mengajarkan kepada orang tua untuk tidak membangkitkan amarah di hati anakanaknya (Ef. 6:4). Artinya, orang tua harus membimbing anak-anaknya dalam kebenaran tanpa melukai hati anak melalui perkataan kasar atau tindakan yang brutal. Orang tua tidak diperkenankan untuk menyalahgunakan otoritas yang diberikan Allah dengan bertindak sesuka hati kepada anak tanpa mempedulikan keadaan si anak. Orang tua harus membimbing anak penuh dengan kasih. Orang tua yang memiliki kasih bukan berarti kehilangan prinsip untuk memberikan disiplin karena kasih menjadi dasar bagi disiplin itu sendiri. Korelasi antara kasih dan disiplin terlihat secara gamblang dalam Amsal 13:24 yang menyatakan, "Siapa tidak menggunakan tongkat, benci kepada anaknya; tetapi siapa mengasihi anaknya, menghajar dia pada waktunya." Orang tua yang bijak hanya akan menghajar anaknya menggunakan tongkat yang mengajar dan 
mengarahkan anaknya kepada kebenaran, bukan tongkat yang melukai anak.

Orang Tua Sebagai Pendorong (Motivator)

Sebagai motivator, orang tua berperan untuk mendorong anak remaja melakukan kegiatan-kegiatan yang menumbuhkan rohani anak-anaknya. Ada banyak orang tua Kristen yang tidak dapat berperan sebagai motivator bagi anak-anak remaja mereka. Bahkan mereka lebih cenderung menjadi seorang hakim yang mengadili anak-anak remaja ketika anak remaja mereka tidak melakukan kegiatan rohani sebagaimana yang mereka harapkan, atau sebaliknya ada orang tua yang bersikap pasif terhadap kegiatan rohani yang dilakukan oleh anak remaja mereka. Bahkan hal yang paling ekstrim, ada orang tua Kristen yang melarang anak-anaknya untuk terlibat dalam kegiatan rohani di gereja. Hal ini terjadi karena orang tua tersebut sesungguhnya tidak memiliki iman yang sejati kepada Tuhan. Itulah sebabnya penulis menambahkan bahwa untuk membina rohani anak remaja, orang tua harus memiliki iman yang sejati terlebih dahulu agar proses

47 Wayne Rice, Help! There's A Teenager in My House (Bandung: Pionir Jaya dan Visi Pressindo, 2006), 233-234. pembinaan rohani remaja dapat berjalan secara efektif.

Sebagai motivator, orang tua seharusnya mendorong anak-anak untuk mengikuti ibadah remaja yang diadakan oleh gereja. $^{47}$ Kegiatan-kegiatan lain yang sebaiknya diikuti oleh remaja adalah retreat, bakti sosial, paduan suara, camping, kunjungan kepada orang sakit, olahraga bersama teman-teman di gereja, dan lain-lain. Selain itu, orang tua juga harus mendukung anak remaja untuk terlibat dalam pelayanan di gereja. Pelayanan yang dilakukan oleh anak remaja akan membuat dia semakin mencintai Tuhan lewat pelayanan yang dilakukannya itu. Pada umumnya, anak remaja dapat terlibat dalam pelayanan pujian, baik sebagai pemimpin pujian (worship leader) maupun sebagai singer, pemain musik, penerima tamu, kolektan, atau tim doa di gereja. Orang tua seyogyanya dapat menggali potensi yang dimiliki oleh anak remaja supaya dapat dikembangkan untuk melayani Tuhan. Dengan demikian, kerohanian anak remaja akan terus terjaga dan bertumbuh karena mereka ada dalam komunitas gerejawi yang pasti mendorong pertumbuhan secara rohani. 
Sebaliknya, jika anak remaja tidak terlibat dalam kegiatan-kegiatan rohani di gereja atau komunitas Kristen lainnya, dia justru akan mencari kegiatan lainnya di luar gereja atau komunitas Kristen tadi. Mereka akan lebih sering bertemu dengan temanteman sekolah yang belum tentu mereka adalah anak-anak yang baik dan mengenal Tuhan. Anak remaja Kristen akan terpengaruh oleh pergaulan dengan temanteman yang tidak seiman atau teman-teman yang tidak takut Tuhan. Akibatnya, anak remaja Kristen justru menjadi hidup tidak takut Tuhan dan kerohaniannya akan tergerus bahkan habis sama sekali. Firman Tuhan berkata: "Janganlah kamu sesat: Pergaulan yang buruk merusak kebiasaan yang baik (1 Kor. 15:33)." Inilah yang harus diperhatikan oleh orang tua Kristen masa kini.

Berdasarkan pemaparan penulis di atas, peran orang tua dalam mewariskan iman bagi pembinaan rohani anak remaja adalah sebagai pendidik, pembimbing, dan pendukung. Ketiga peran tersebut sangat penting untuk dilakukan oleh orang tua dengan tuntunan dan bimbingan Roh Kudus.

\section{KESIMPULAN}

Masa remaja merupakan masa transisi yang penuh dengan gejolak. Anak remaja memerlukan peran orang tua untuk membantu mereka menghadapi gejolak dalam hidup mereka. Orang tua memiliki peran yang vital bagi pembinaan rohani remaja dengan mewariskan iman dalam keluarga. Tuhan memberikan amanat ini kepada semua orang tua Kristen agar anak remaja dapat bertumbuh menjadi pribadi yang tidak menyimpang dari jalan yang benar. Firman Tuhan dalam 2 Timotius 1:5 telah memberikan deskripsi tentang peran orang tua dalam mewariskan iman bagi kepentingan pertumbuhan rohani anak remaja yaitu sebagai pendidik (edukator), pembimbing (mentor), dan pendorong (motivator). Sebagai pendidik (edukator), orang tua berperan untuk mengajarkan firman Tuhan dan memberikan teladan. Sedangkan sebagai pembimbing (mentor), orang tua berperan untuk mengawasi pertumbuhan rohani anak. Yang terakhir, sebagai pendorong (motivator) orang tua berperan mendorong anak untuk melakukan kegiatan-kegiatan rohani di rumah, sekolah, dan gereja.

\section{REFERENSI}

Adiansah, Wandi, Eko Setiawan, Wina Nurdini Kodaruddin, and Hery Wibowo. "Person in Environment Remaja Pada Era Revolusi Industri 4.0.” Focus : Jurnal Pekerjaan Sosial 2, no. 1 
(2019): 47.

Bailey, Mark L. "Teologi Dari Surat-Surat Penggembalaan Paulus.” In A Biblical Theology of New Testament, edited by Roy B. Zuck. Malang: Gandum Mas, 2011.

Diana, Ruat. "Prinsip Teologi Kristen Pendidikan Orang Tua Terhadap Anak Di Era Revolusi Industri 4.0." BIA': Jurnal Teologi dan Pendidikan Kristen Kontekstual 2, no. 1 (2019): 27-39.

Duyverman, M. E. Pembimbing Ke Dalam Perjanjian Baru. Jakarta: BPK Gunung Mulia, 2012.

Fantini, Mario, and Rene Cardenas. Parenting in a Multiculture Society.

New York: Longman, 1980.

Fee, Gordon D. 1 and 2 Timothy, Titus: New International Biblical Commentary. Massachusetts: Hendrickson Publishers, 1988.

Gaebelein, Frank E. The Expositor's Bible

Commentary Volume 11. Grand Rapids: Zondervan Publishing House, n.d.

Grinnell, Ann. Pembacaan Wajib PAK Remaja-Pemuda. Makassar: STT Jaffray, 2012.

Guthrie, Donald. The Pastoral Epistles: Tyndale New Testament Commentaries. Grand Rapids: Eerdmans Publishing Company, 1957.
Guthrie, Donald, Alec Motyer, Alan M. Stibbs, and Donald J. Wiseman. Tafsiran Alkitab Masa Kini 3: MatiusWahyu. Jakarta: Yayasan Komunikasi Bina Kasih, 2006.

Hadinoto, N. K. A. Dialog Dan Edukasi. Jakarta: BPK Gunung Mulia, 1999. Haystead, Wes. Mengenalkan Allah Kepada Anak. Yogyakarta: Yayasan Gloria, 2000.

Hendriks, Howard. Membina Temperamen Anda. Bandung: Kalam Hidup, 1982.

Hoekema, Anthony A. Manusia: Ciptaan Menurut Gambar Allah. Surabaya: Momentum, 2003.

Hurlock, Elizabeth B. Psikologi Perkembangan: Suatu Pendekatan Sepanjang Rentang Kehidupan. Jakarta: Erlangga, 2002.

Kusmiyati. "Berbagai Perilaku Kenakalan Remaja Yang Mengkhawatirkan Health Liputan6.Com." Last modified September 10, 2013. Accessed January 24 , 2021. https://www.liputan6.com/health/read/6 88614/berbagai-perilaku-kenakalanremaja-yang-mengkhawatirkan.

Nazir, Moh. Metode Penelitian. Jakarta: Ghalia Indonesia, 1988.

Ndraha, Roswitha, and Julianto Simanjuntak. Sembilan Masalah Utama Remaja. 
Jakarta: Yayasan Peduli Konseling Indonesia, 2009.

Peter, Ramot. "Peran Orangtua Dalam Krisis

Remaja." Humaniora 6, no. 4 (2015): 453.

Pratama, Hellen Chou. Cyber Smart Parenting. Bandung: Visi Anugerah Indah, 2012.

Rice, Wayne. Help! There's A Teenager in My House. Bandung: Pionir Jaya dan Visi Pressindo, 2006.

Richards, Lawrence O. Pelayanan Kepada Anak-Anak. Bandung: Kalam Hidup, 2007.

Sahartian, Santy. "Pengaruh Pembinaan Rohani Keluarga Terhadap Karakter Pemuda Berdasarkan Kolose 2: 6-10 Di GBAP Surakarta." FIDEI: Jurnal Teologi Sistematika dan Praktika 2, no. 1 (2019): 20-39.

Stott, John R. W. Pemahaman Dan Penerapan Amanat 2 Timotius. Jakarta: Yayasan Komunikasi Bina Kasih, 1991. Subagyo, Andreas B. Pengantar Riset Kuantitatif Dan Kualitatif. Bandung: Kalam Hidup, 2004.

Susabda, Yakub. Marriage Enrichment:

Pembinaan Keluarga Kristen. Jakarta:

Mitra Pustaka dan Pionir Jaya, 2011.

Thompson, Marjoric L. Keluarga Sebagai

Pusat Pembentukan. Jakarta: BPK
Gunung Mulia, 2011.

Tulluan, Ola. Introduksi Perjanjian Baru.

Batu: Departemen Literatur YPPII, 1999.

Wagiu, Nandari Prastica. "Implementasi Peran Orang Tua Menurut Ulangan 6:49 Dalam Pendidikan Agama Kristen Keluarga Di Gereja Masehi Injili Di Minahasa Jemaat Imanuel Aertembaga Bitung." Shanan 2, no. 2 (2020): 128161.

Wiriadinata, Susie. Orang Tua Idaman. Bandung: Lembaga Literatur Baptis, 1999.

Yuliawati, Livia, and Bhaktiar Sihombing. "Membangun Karakter: Sekilas Potret Kebutuhan Remaja Di Sekolah Kristen.” Jurnal Teologi Reformed Indonesia 4, no. 1 (2014): 19-28.

\section{Alkitab Penuntun Hidup Berkelimpahan.}

Malang: Gandum Mas, 1994.

"Polisi Anggap Penganiayaan Rombongan

Pelajar Di Bantul Sebagai Kenakalan Remaja." Accessed January 24, 2021. https://nasional.kompas.com/read/2016/ 12/14/18072041/polisi.anggap.pengani ayaan.rombongan.pelajar.di.bantul.seba gai.kenakalan.remaja.

"Viral Video Siswa Minum Anggur Merah Di Kelas, Lokasi Diduga Bukan Daerah Jakarta Utara." Accessed January 24, 
Jurnal Gamaliel : Teologi Praktika

Vol 3, No 1, Maret 2021

2021.

https://megapolitan.kompas.com/read/2

019/09/02/22383871/viral-video-siswa- minum-anggur-merah-di-kelas-lokasididuga-bukan-daerah. 